\title{
Water activity and glass transition in dairy ingredients
}

\author{
Pierre SCHUCK ${ }^{\mathrm{a} *}$, Eric BLANCHARD ${ }^{\mathrm{b}}$, Anne DOLIVET ${ }^{\mathrm{a}}$, \\ Serge MÉJEAN ${ }^{a}$, Evelyne ONILLON ${ }^{b}$, Romain JEANTET ${ }^{a}$ \\ ${ }^{a}$ UMR 1253 Science et Technologie du Lait et de l'Euf, Inra-Agrocampus Rennes, 65 rue de St-Brieuc, \\ 35042 Rennes cedex, France \\ ${ }^{\mathrm{b}}$ Laiterie de Montaigu, ZI du Planty, 85807 Montaigu, France
}

Published online 21 June 2005

\begin{abstract}
The glass transition temperatures $\left(\mathrm{T}_{\mathrm{g}}\right)$ of various dairy powders were determined by differential scanning calorimetry among the sorptions isotherm, and were also calculated using the extended Couchman-Karasz equation, taking into account the dry values of $\mathrm{T}_{\mathrm{g}}$ and $\Delta \mathrm{Cp}$ (heat capacity changes during glass transition) and the contents in each amorphous component category. The results obtained showed a statistically significant correspondence between measured and calculated $\mathrm{T}_{\mathrm{g}}$ inflection values: the model gives an approximate inflection value of $\mathrm{T}_{\mathrm{g}}$ corresponding to the measured one $\pm 14{ }^{\circ} \mathrm{C}$. This lack of fit can be explained both by the accuracy of measurement of $\mathrm{T}_{\mathrm{g}}$ and by not considering minor constituents of dairy powders (minerals and oligosaccharides) in calculation. From the values of $\mathrm{T}_{\mathrm{g}}$ and $\Delta \mathrm{Cp}$ measured and/or calculated in this study, it is possible to anticipate the behavior of a dairy powder under given temperature $(\mathrm{T})$ and water activity $\left(\mathrm{a}_{\mathrm{w}}\right)$ conditions during drying and storage with regard to stickiness and caking. We propose the calculation of a stickiness and caking sensitivity index according to the values of [ $\left.\mathrm{T}-\mathrm{T}_{\mathrm{g}}\right]$ and $\Delta \mathrm{Cp}$, whose value is in agreement with the expected behavior of various dairy powders during drying and storage.
\end{abstract}

water activity / glass transition / dairy powder / stickiness / caking

Résumé - Activité de l'eau et transition vitreuse de divers ingrédients laitiers. Les températures de transition vitreuse $\left(\mathrm{T}_{\mathrm{g}}\right)$ de différents ingrédients laitiers ont été déterminées par calorimétrie différentielle sur l'ensemble de l'isotherme de sorption, et calculées par l'équation de CouchmanKarasz étendue à plus de trois constituants. Cette équation prend en compte les valeurs sèches de $T_{g}$ et $\Delta \mathrm{Cp}$ (variation de chaleur spécifique mesurée lors de la transition vitreuse) et la fraction massique de chaque catégorie de constituant amorphe. Les résultats obtenus montrent une corrélation statistiquement significative entre les valeurs de $\mathrm{T}_{\mathrm{g}}$ mesurées et calculées : le modèle utilisé permet ainsi d'obtenir une estimation de la valeur de $\mathrm{T}_{\mathrm{g}}$ correspondant à la valeur mesurée $\pm 14^{\circ} \mathrm{C}$. L'écart d'ajustement peut s'expliquer par les erreurs de mesure et par la non-prise en compte des constituants mineurs dans le calcul (minéraux, oligosaccharides). A partir des valeurs de $\mathrm{T}_{\mathrm{g}}$ et $\Delta \mathrm{Cp}$ mesurées et/ou calculées, il est possible d'anticiper le comportement d'une poudre laitière dans des conditions données de température $(\mathrm{T})$ et d'activité d'eau $\left(\mathrm{a}_{\mathrm{w}}\right)$ au cours du séchage et du stockage, vis à vis du collage et du mottage. Nous proposons le calcul d'un indice de sensibilité au collage et au mottage à partir des valeurs de $\left[\mathrm{T}-\mathrm{T}_{\mathrm{g}}\right]$ et $\Delta \mathrm{Cp}$, dont la valeur est cohérente avec le comportement connu de différentes poudres laitières au cours du séchage et du stockage.

activité de l'eau / transition vitreuse / poudre laitière / collage / mottage

* Corresponding author: pierre.schuck@rennes.inra.fr 


\section{INTRODUCTION}

Spray drying, storage and quality of milk powder are significantly dependent on both the physical state of the lactose (one of the main components in skim milk powder) and on the proteins or other carbohydrates which themselves are dependent on the glass transition temperature $\left(\mathrm{T}_{\mathrm{g}}\right)$. The spray drying of skim milk concentrate is so quick that the lactose cannot crystallize [18]. Rapid removal of water in subsequent spray drying does not allow lactose crystallization, and when water is removed, lactose is transformed into a solid-like, amorphous glass directly from the dissolved state [9-11, 17, 18].

Many dehydrated foods contain amorphous components in the glass form. This is a non-equilibrium state with higher energy in relation to the corresponding equilibrium state. If the temperature of a material in this state rises above a certain critical value then it transforms into a rubber. This phenomenon is known as glass transition and the temperature at which it occurs is the glass transition range temperature. This transition results in an increase in mobility in the rubbery state and this in turn can lead to change in physical and chemical properties of the material. Carbohydrates, including sugars, starch and hemicelluloses can exist in the amorphous glassy state in dried foods. Low molecular weight sugars in the glassy state are usually extremely hygroscopic and have low glass transition temperatures [2]. This can lead to problems in spray drying and/or in storage. The addition of high molecular weight compounds to these low molecular weight sugars can lead to an improvement in spray drying and storage conditions. Proteins, including gelatin, elastin, gluten, glutenin, casein, whey proteins and lysozyme, are also found in the amorphous state in dried food. In the dry state, they have a relatively a high glass transition temperature $[2,12,15]$.

The aim of the present study was to evaluate the moisture sorption isotherm, glass transition temperature $\left(\mathrm{T}_{\mathrm{g}}\right)$ and state diagrams ( $T_{g}$ vs. moisture) for various dairy ingredients (caseinate, whey proteins, and crystallized and non-crystallized whey, skim milk and hydrolyzed skim milk powders).
From this information, we should be able to determine the glass transition temperature of any product with regard to the physical properties of its major ingredients by using the Couchman-Karasz equation [5], modified and extended in tertiary mixtures of casein, carbohydrates and water. From this thermodynamic information, one should be able to anticipate the behavior of a powder under given temperature and $\mathrm{a}_{\mathrm{w}}$ conditions.

\section{MATERIALS AND METHODS}

\subsection{Dairy powders}

The native phosphocaseinate suspension (NPCS) was prepared by microfiltration and diafiltration (pore diameter: $0.1 \mu \mathrm{m}$ ) on MFS 19 equipment (Tetra-Laval, Ảarhus, Denmark; $4.6 \mathrm{~m}^{2}$ ) at $50{ }^{\circ} \mathrm{C}[6,16]$, at $200 \pm$ $5 \mathrm{~g} \cdot \mathrm{kg}^{-1}$ total solids. The whey protein isolate (WPI) was obtained by ultrafiltration and diafiltration on a DDS module (Gea, Soeborg, Denmark) with a plane membrane $\left(10000 \mathrm{~g} \cdot \mathrm{mol}^{-1}\right.$ molecular mass cut-off, $9 \mathrm{~m}^{2}$; $50{ }^{\circ} \mathrm{C}$ ) at $200 \pm 2 \mathrm{~g} \cdot \mathrm{kg}^{-1}$ total solids. Concentrated milk and whey were produced in a two-stage falling film vacuum evaporation (GEA, Niro Atomizer, St Quentin en Yvelines, France) at Bionov (Rennes, France). The first evaporation stage was carried out at $60{ }^{\circ} \mathrm{C}$ and led to a concentrated milk and whey temperature of $40{ }^{\circ} \mathrm{C}$. The evaporation capacity was $180 \mathrm{~kg} \cdot \mathrm{h}^{-1}$. A part of the concentrated whey was crystallized at $25^{\circ} \mathrm{C}$ for $5 \mathrm{~h}$ to obtain a crystallized whey concentrated. The spray drying of concentrates of NPCS, WPI, skim milk (SM), crystallized $(\mathrm{CW})$ and non-crystallized whey (NCW) were performed at Bionov (Rennes, France) in a 3-stage pilot-plant spray dryer (GEA, Niro Atomizer, St Quentin en Yvelines, France) [22]. The atomizer was equipped with a pressure nozzle $(0.73-\mathrm{mm}$ diameter orifice) and a 4 slot core (0.51-mm nominal width), providing a $60^{\circ}$ spray angle. Evaporation capacity was 70 to $120 \mathrm{~kg} \cdot \mathrm{h}^{-1}$ (depending on inlet and outlet air temperature and air flow). The hydrolyzed skim milk (HSM) and sodium caseinate $(\mathrm{Na}$ caseinate) powders were produced by "La Laiterie de Montaigu” (Montaigu, France) 
Table I. Biochemical composition of dairy powders.

\begin{tabular}{lcrccc}
\hline Powders & Casein & Whey proteins & Lactose & Glucose & Galactose \\
\cline { 2 - 6 } & \multicolumn{5}{c}{$\left(\mathrm{g} \cdot 100 \mathrm{~g}^{-1} \mathrm{TS}\right)$} \\
\hline Non-Crystallized Whey & - & $13.2 \pm 0.2$ & $78.9 \pm 1.2$ & - & - \\
Crystallized Whey & - & $13.5 \pm 0.2$ & $76.3 \pm 1.2$ & - & - \\
Skim Milk & $27.2 \pm 0.1$ & $5.4 \pm 0.2$ & $54.8 \pm 0.9$ & - & - \\
Hydrolyzed Skim Milk & $28.3 \pm 0.2$ & $5.7 \pm 0.5$ & $6.7 \pm 1.2$ & $23.1 \pm 1.5$ & $20.7 \pm 1.5$ \\
Native Phosphocaseinate Suspension & $84.5 \pm 0.2$ & $4.3 \pm 0.5$ & $1.8 \pm 0.5$ & - & - \\
NPCS) & - & $85.8 \pm 0.1$ & $3.8 \pm 0.5$ & - & - \\
Whey Protein Isolate (WPI) & - & - & $2.2 \pm 0.5$ & - & - \\
Na Caseinate & $91.9 \pm 0.2$ & -
\end{tabular}

with a lactose hydrolysis ratio of $89 \%$ and by "Armor Proteines" (Saint Brice en Coglès, France), respectively.

\subsection{Chemical and physical analysis}

Free water content was calculated by weight loss after drying $5 \mathrm{~g}$ of the samples with sand in a forced air oven at $105^{\circ} \mathrm{C}$ for $7 \mathrm{~h}$ (liquid) or $5 \mathrm{~h}$ (powder). Total water content was determined by weight loss after drying $5 \mathrm{~g}$ of the sample under vacuum with sand in a forced air oven at $105{ }^{\circ} \mathrm{C}$ for $5 \mathrm{~h}$ [20]. Crystallization ratios were determined by calculating the difference between total water and free water content [20]. Casein and whey protein contents were determined according to $[1,19]$. The lactose, galactose and glucose contents were determined by enzymatic reactions (Boehringer Mannheim, Biopharm AG, Darmstadt, Germany). The biochemical composition of the dairy powders is reported in Table I.

Water activity $\left(\mathrm{a}_{\mathrm{w}}\right)$ was measured in a water activity-meter $\left(\mathrm{a}_{\mathrm{w}}\right.$-meter; Novasina RTD 200/0 and RTD 33, Pfäffikon, Switzerland) at $20{ }^{\circ} \mathrm{C}$.

"Working" moisture adsorption isotherms were determined using the method proposed by [15]. Approximately 2-g samples of dairy powders were weighed in stainless steel dishes and placed in a desiccator which contained a saturated salt solution at an $\mathrm{a}_{\mathrm{w}}$ between 0.11 and 0.66. The saturated salt solutions used were $\mathrm{LiCl}$, $\mathrm{CH}_{3} \mathrm{COOK}, \mathrm{MgCl}_{2}, \mathrm{NaI}, \mathrm{K}_{2} \mathrm{CO}_{3}, \mathrm{NaBr}$,
$\mathrm{Mg}\left(\mathrm{NO}_{3}\right)$ and $\mathrm{NaNO}_{2}$ with relative humidity $(\mathrm{RH})$ of $11,22,33,39,43,54,57$ and $66 \%( \pm 1 \% \mathrm{RH})$, respectively, giving $\mathrm{a}_{\mathrm{w}}$ of $0.01 \times$ percentage of $\mathrm{RH}$ at equilibrium [15]. The desiccators were then placed in temperature-controlled chambers $\left( \pm 2{ }^{\circ} \mathrm{C}\right)$ at $20{ }^{\circ} \mathrm{C}$, and samples were allowed to equilibrate for $15 \mathrm{~d}$. Preliminary experiments showed that the dairy powders reached relative humidity equilibrium at $20^{\circ} \mathrm{C}$, whether by adsorption or desorption, within $10 \mathrm{~d}$. However, to ensure a constant $\mathrm{a}_{\mathrm{w}}$, dairy powder samples were equilibrated for fifteen days prior to use.

Glass transition temperatures $\left(\mathrm{T}_{\mathrm{g}}\right)$ and heat capacity changes $(\Delta \mathrm{Cp})$ were determined using differential scanning calorimetry (DSC) (Q-1000, TA Instruments, Saint Quentin en Yvelines, France) calibrated with indium (melting point $156.6{ }^{\circ} \mathrm{C}$ ). The samples were scanned twice to eliminate the hysteresis effect of thermal relaxation that is typical for glass transition. The initial scanning rate was $5{ }^{\circ} \mathrm{C} \cdot \mathrm{min}^{-1}$ from $-70^{\circ} \mathrm{C}$ to $+70^{\circ} \mathrm{C}$ for the skim milk, hydrolyzed skim milk, and crystallized and non-crystallized whey powders, and from $0{ }^{\circ} \mathrm{C}$ to $+130{ }^{\circ} \mathrm{C}$ for the NPCS and WPI powders. Samples were cooled at $10^{\circ} \mathrm{C} \cdot \mathrm{min}^{-1}$ at $-70{ }^{\circ} \mathrm{C}$, and the $\mathrm{T}_{\mathrm{g}}$ range was determined from the DSC curve of the second scan at $5{ }^{\circ} \mathrm{C} \cdot \mathrm{min}^{-1}$ from $-70{ }^{\circ} \mathrm{C}$ to $+250{ }^{\circ} \mathrm{C}$ (Fig. 1), giving three values: $\mathrm{T}_{\mathrm{g}}$ onset, $\mathrm{T}_{\mathrm{g}}$ inflection and $\mathrm{T}_{\mathrm{g}}$ endset. The $\Delta \mathrm{Cp}$ value was given by the change in heat capacity between onset and endset $\mathrm{T}_{\mathrm{g}}$ values. 


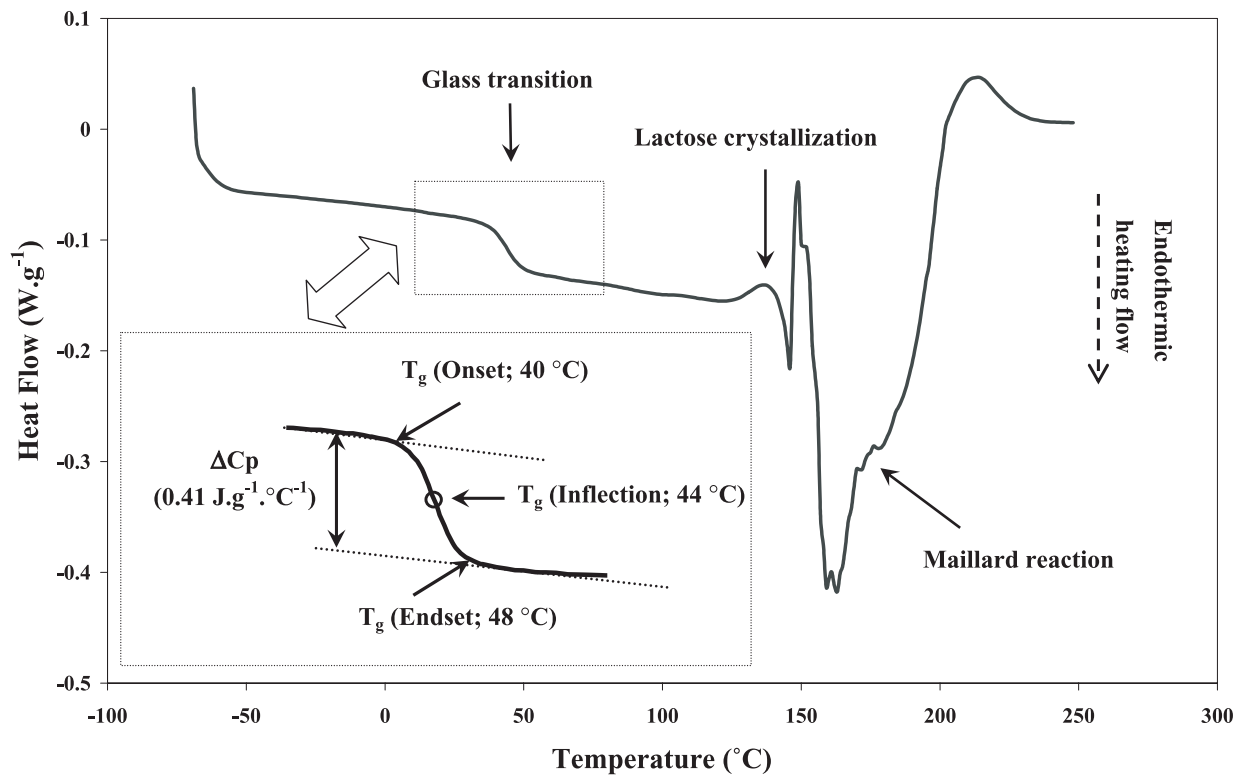

Figure 1. DSC curve of the second scan obtained with non-crystallized whey powder at $0.22 \mathrm{a}_{\mathrm{w}}$.

\subsection{Statistical analysis}

For each powder from the same batch, three replications of moisture adsorption isotherms, glass transition temperatures and heat capacity change determination were performed. The Student's $t$ test was used as a guide for pair comparisons of the trial means. Differences among trials that are subsequently described as being significant were determined at $P<0.05$.

Comparison between measured and predicted $\mathrm{T}_{\mathrm{g}}$ values was performed using linear regression. Fitting between values provided by the extended Couchman-Karasz equation and the experimental data was estimated by the multiple correlation coefficient $\left(R^{2}\right)$ and a Fisher $F$ test. Significance was determined at $P<0.001$.

\section{RESULTS AND DISCUSSION}

The $\mathrm{T}_{\mathrm{g}}$ and $\Delta \mathrm{Cp}$ measured at various relative humidities are reported in Tables II, III, IV, V, VI and VII for the non-crystallized whey (NCW), crystallized whey (CW), skim milk (SM), hydrolyzed skim milk (HSM), and NPCS and WPI powders, respectively.

In all cases and according to the literature, the increase in the relative humidity during the sorption isotherm involves that of the product water content, leading to a reduction in the glass transition temperature $\mathrm{T}_{\mathrm{g}}[8,13]$. Indeed, and according to the Couchman-Karasz equation [5] extended in tertiary mixtures of casein, carbohydrates and water (Eq. (1)), the glass transition temperature from a product is the gravity center of the glass transition temperatures from its components:

$\mathrm{T}_{\mathrm{g}}=\frac{\mathrm{W}_{1} \Delta \mathrm{Cp}_{1} \mathrm{~T}_{\mathrm{g} 1}+\mathrm{W}_{2} \Delta \mathrm{Cp}_{2} \mathrm{~T}_{\mathrm{g} 2}+\mathrm{W}_{3} \Delta \mathrm{Cp}_{3} \mathrm{~T}_{\mathrm{g} 3}}{\mathrm{~W}_{1} \Delta \mathrm{C} \mathrm{p}_{1}+\mathrm{W}_{2} \Delta \mathrm{Cp}_{2}+\mathrm{W}_{3} \Delta \mathrm{Cp}_{3}}$

where $\mathrm{T}_{\mathrm{gi}}$ is the glass transition temperature of a component $\mathrm{i}(\mathrm{K}), \Delta \mathrm{Cp} \mathrm{p}_{\mathrm{i}}$ is the change in heat capacity of this component at $\mathrm{T}_{\mathrm{gi}}$ $\left(\mathrm{J} \cdot \mathrm{kg}^{-1} \cdot{ }^{\circ} \mathrm{C}^{-1}\right)$ and $\mathrm{W}_{\mathrm{i}}$ its weight fraction. The components taken into account are supposed to be miscible, which excludes the insoluble fractions such as crystallized lactose or calcium phosphate precipitate, for example. 
Table II. Non-crystallized whey powder: free water content, glass transition temperature $\left(\mathrm{T}_{\mathrm{g}}\right)$, change in heat capacity $(\Delta \mathrm{Cp})$ and crystallization ratio at various relative humidities.

\begin{tabular}{|c|c|c|c|c|c|c|}
\hline $\begin{array}{l}\text { Relative } \\
\text { Humidity } \\
(\%)\end{array}$ & $\begin{array}{c}\text { Free water } \\
\text { content } \\
\left(\mathrm{g} .100 \mathrm{~g}^{-1} \mathrm{TS}\right)\end{array}$ & $\begin{array}{c}\text { Glass transition } \\
\text { temperature } \\
\text { (onset }-{ }^{\circ} \mathrm{C} \text { ) }\end{array}$ & $\begin{array}{l}\text { Glass transition } \\
\text { temperature } \\
\text { (inflection }-{ }^{\circ} \mathrm{C} \text { ) }\end{array}$ & $\begin{array}{c}\text { Glass transition } \\
\text { temperature } \\
\left.\text { (endset }-{ }^{\circ} \mathrm{C}\right)\end{array}$ & $\begin{array}{c}\text { Change in heat } \\
\text { capacity } \\
\left(\mathrm{J} \cdot \mathrm{g}^{-1 .} \cdot{ }^{\circ} \mathrm{C}^{-1}\right)\end{array}$ & $\begin{array}{c}\text { Crystallization } \\
\text { ratio } \\
(\%)\end{array}$ \\
\hline 11 & $4.2 \pm 0.1$ & $49 \pm 2$ & $51 \pm 1$ & $52 \pm 1$ & $0.38 \pm 0.02$ & 12.2 \\
\hline 22 & $4.8 \pm 0.2$ & $40 \pm 1$ & $44 \pm 1$ & $47 \pm 1$ & $0.42 \pm 0.05$ & 13.9 \\
\hline 33 & $7.4 \pm 0.1$ & $24 \pm 1$ & $29 \pm 1$ & $32 \pm 2$ & $0.50 \pm 0.02$ & 11.6 \\
\hline 39 & $8.9 \pm 0.1$ & $17 \pm 2$ & $21 \pm 2$ & $25 \pm 2$ & $0.51 \pm 0.02$ & 11.9 \\
\hline 43 & $10.1 \pm 0.1$ & $12 \pm 1$ & $15 \pm 1$ & $18 \pm 1$ & $0.53 \pm 0.02$ & 13.9 \\
\hline 53 & $5.7 \pm 0.1$ & $-28 \pm 2$ & $-15 \pm 2$ & $-10 \pm 2$ & $0.09 \pm 0.02$ & 72.8 \\
\hline 57 & $5.9 \pm 0.1$ & $-37 \pm 2$ & $-22 \pm 2$ & $-14 \pm 3$ & $0.12 \pm 0.02$ & 76.2 \\
\hline 66 & $7.4 \pm 0.2$ & $-54 \pm 2$ & $-35 \pm 3$ & $-24 \pm 2$ & $0.15 \pm 0.03$ & 81.5 \\
\hline
\end{tabular}

Table III. Crystallized whey powder: free water content, glass transition temperature $\left(\mathrm{T}_{\mathrm{g}}\right)$, change in heat capacity $(\Delta \mathrm{Cp})$ and crystallization ratio at various relative humidities.

\begin{tabular}{lcccccc}
\hline $\begin{array}{l}\text { Relative } \\
\text { Humidity } \\
(\%)\end{array}$ & $\begin{array}{c}\text { Free water } \\
\text { content } \\
\left(\mathrm{g} \cdot 100 \mathrm{~g}^{-1} \mathrm{TS}\right)\end{array}$ & $\begin{array}{c}\text { Glass transition } \\
\text { temperature } \\
\left(\text { onset }-{ }^{\circ} \mathrm{C}\right)\end{array}$ & $\begin{array}{c}\text { Glass transition } \\
\text { temperature } \\
\left.\text { (inflection }-{ }^{\circ} \mathrm{C}\right)\end{array}$ & $\begin{array}{c}\text { Glass transition } \\
\text { temperature } \\
\left(\text { endset }-{ }^{\circ} \mathrm{C}\right)\end{array}$ & $\begin{array}{c}\text { Change in heat Crystallization } \\
\text { capacity } \\
\left(\mathrm{J} \cdot \mathrm{g}^{-1 .} \cdot \mathrm{C}^{-1}\right)\end{array}$ & $\begin{array}{c}\text { ratio } \\
(\%)\end{array}$ \\
\hline 11 & $2.2 \pm 0.1$ & $39 \pm 1$ & $44 \pm 1$ & $48 \pm 1$ & $0.18 \pm 0.01$ & 61.9 \\
22 & $2.6 \pm 0.2$ & $25 \pm 2$ & $30 \pm 1$ & $36 \pm 2$ & $0.24 \pm 0.02$ & 68.0 \\
33 & $3.9 \pm 0.2$ & $14 \pm 1$ & $15 \pm 2$ & $17 \pm 1$ & $0.06 \pm 0.02$ & 70.7 \\
39 & $4.3 \pm 0.1$ & $1 \pm 1$ & $2 \pm 1$ & $3 \pm 2$ & $0.04 \pm 0.01$ & 72.8 \\
43 & $4.8 \pm 0.2$ & $-3 \pm 1$ & $-2 \pm 1$ & $-1 \pm 1$ & $0.03 \pm 0.01$ & 72.4 \\
53 & $4.6 \pm 0.1$ & $-22 \pm 3$ & $-16 \pm 3$ & $-6 \pm 3$ & $0.10 \pm 0.02$ & 82.8 \\
57 & $4.9 \pm 0.2$ & $-35 \pm 3$ & $-21 \pm 3$ & $-13 \pm 2$ & $0.11 \pm 0.02$ & 82.8 \\
66 & $6.5 \pm 0.1$ & $-42 \pm 4$ & $-27 \pm 3$ & $-21 \pm 2$ & $0.15 \pm 0.02$ & 91.1 \\
\hline
\end{tabular}

$\Delta \mathrm{Cp}$ is representative of the extent of the biochemical modifications that occur during glass transition (i.e. around the $\mathrm{T}_{\mathrm{g}}$ range) or changes in state (crystallization and fusion). In the case of glass transition, which corresponds to the change from a high viscosity amorphous liquid to a low viscosity amorphous liquid, its value is directly in relation to the amplitude of the changes within the product. The results obtained in this study show that $\Delta \mathrm{Cp}$ is extremely variable according to the product with constant water activity. As an example, for a $0.22 \mathrm{a}_{\mathrm{w}}$, its value is between 0.13 (WPI) and 0.42 (NCW). Generally, the value of $\Delta \mathrm{Cp}$ is determined by the concentration and the nature (amorphous, crystallized) of the lactose present.

The values obtained for the crystallized and non-crystallized whey are given in
Tables II and III. We observed a reduction in $\mathrm{T}_{\mathrm{g}}$ in relation to the increase in relative humidity and free water content, which is in agreement with the literature [17]. At the same time, $\Delta \mathrm{Cp}$ value increased until crystallization of lactose occurred beyond $43 \%$ of HR in both cases (in accordance with the literature), and then decreased. In the first part of the sorption isotherm (below $43 \%$ of $\mathrm{HR}$ ), the values of $\mathrm{T}_{\mathrm{g}}$ and $\Delta \mathrm{Cp}$ of the $\mathrm{NCW}$ were significantly higher than those of the $\mathrm{CW}$, corresponding to the quantity of amorphous lactose present in these powders. Glass transition can occur only on amorphous components, and is not related to the crystallized state.

Simultaneous reduction in water content, related to the release of water molecules by lactose [18], and considerable reduction in 
Table IV. Skim milk powder: free water content, glass transition temperature $\left(T_{g}\right)$, change in heat capacity $(\Delta \mathrm{Cp})$ and crystallization ratio at various relative humidities.

\begin{tabular}{lcccccc}
\hline $\begin{array}{l}\text { Relative } \\
\text { Humidity }\end{array}$ & $\begin{array}{c}\text { Free water } \\
\text { content } \\
\left(\mathrm{g} \cdot 100 \mathrm{~g}^{-1} \mathrm{TS}\right)\end{array}$ & $\begin{array}{c}\text { Glass transition } \\
\text { temperature } \\
\left(\text { onset }-{ }^{\circ} \mathrm{C}\right)\end{array}$ & $\begin{array}{c}\text { Glass transition } \\
\text { temperature } \\
\left.\text { (inflection }-{ }^{\circ} \mathrm{C}\right)\end{array}$ & $\begin{array}{c}\text { Glass transition } \\
\text { temperature } \\
\left(\text { endset }-{ }^{\circ} \mathrm{C}\right)\end{array}$ & $\begin{array}{c}\text { Change in heat Crystallization } \\
\text { capacity } \\
\left(\mathrm{J} \cdot \mathrm{g}^{-1} \cdot{ }^{\circ} \mathrm{C}^{-1}\right)\end{array}$ & $\begin{array}{c}\text { ratio } \\
(\%)\end{array}$ \\
\hline 11 & $4.4 \pm 0.1$ & $45 \pm 2$ & $49 \pm 1$ & $51 \pm 1$ & $0.23 \pm 0.02$ & 0.3 \\
22 & $5.4 \pm 0.2$ & $39 \pm 1$ & $42 \pm 1$ & $46 \pm 1$ & $0.25 \pm 0.03$ & -2.1 \\
33 & $7.3 \pm 0.1$ & $22 \pm 1$ & $25 \pm 1$ & $30 \pm 1$ & $0.32 \pm 0.02$ & 5.5 \\
39 & $8.6 \pm 0.1$ & $15 \pm 1$ & $20 \pm 1$ & $23 \pm 1$ & $0.33 \pm 0.01$ & 6.0 \\
43 & $9.3 \pm 0.1$ & $5 \pm 1$ & $12 \pm 2$ & $17 \pm 2$ & $0.26 \pm 0.01$ & 7.4 \\
53 & $8.4 \pm 0.1$ & $-9 \pm 3$ & $-1 \pm 3$ & $1 \pm 3$ & $0.29 \pm 0.01$ & 30.2 \\
57 & $8.8 \pm 0.2$ & $-16 \pm 3$ & $-9 \pm 2$ & $-2 \pm 3$ & $0.33 \pm 0.00$ & 50.6 \\
66 & $9.2 \pm 0.2$ & $-31 \pm 4$ & $-24 \pm 4$ & $-6 \pm 3$ & $0.36 \pm 0.01$ & 57.6 \\
\hline
\end{tabular}

Table V. Hydrolyzed skim milk powder: free water content, glass transition temperature $\left(T_{g}\right)$, change in heat capacity $(\Delta \mathrm{Cp})$ and crystallization ratio at various relative humidities.

\begin{tabular}{lccccc}
\hline $\begin{array}{l}\text { Relative } \\
\text { Humidity }\end{array}$ & $\begin{array}{c}\text { Free water } \\
\text { content } \\
\left(\mathrm{g} \cdot 100 \mathrm{~g}^{-1} \mathrm{TS}\right)\end{array}$ & $\begin{array}{c}\text { Glass transition } \\
\text { temperature } \\
\left(\text { onset }-{ }^{\circ} \mathrm{C}\right)\end{array}$ & $\begin{array}{c}\text { Glass transition } \\
\text { temperature } \\
\left.\text { inflection }-{ }^{\circ} \mathrm{C}\right)\end{array}$ & $\begin{array}{c}\text { Glass transition } \\
\text { temperature } \\
\left(\text { endset }-{ }^{\circ} \mathrm{C}\right)\end{array}$ & $\begin{array}{c}\text { Change in heat } \\
\text { capacity } \\
\left(\mathrm{J} \cdot \mathrm{g}^{-1 .} \cdot{ }^{\circ} \mathrm{C}^{-1}\right)\end{array}$ \\
\hline 11 & $5.8 \pm 0.1$ & $10 \pm 2$ & $13 \pm 1$ & $18 \pm 1$ & $0.28 \pm 0.01$ \\
22 & $7.7 \pm 0.1$ & $-5 \pm 1$ & $2 \pm 1$ & $9 \pm 2$ & $0.32 \pm 0.02$ \\
33 & $9.9 \pm 0.1$ & $-15 \pm 1$ & $-10 \pm 1$ & $-5 \pm 3$ & $0.41 \pm 0.03$ \\
39 & $11.9 \pm 0.1$ & $-21 \pm 1$ & $-15 \pm 1$ & $-10 \pm 1$ & $0.42 \pm 0.03$ \\
43 & $12.4 \pm 0.1$ & $-27 \pm 2$ & $-18 \pm 2$ & $-14 \pm 2$ & $0.45 \pm 0.05$ \\
53 & $15.8 \pm 0.2$ & $-34 \pm 3$ & $-28 \pm 1$ & $-22 \pm 2$ & $0.48 \pm 0.01$ \\
57 & $16.4 \pm 0.1$ & $-38 \pm 3$ & $-30 \pm 2$ & $-23 \pm 3$ & $0.51 \pm 0.02$ \\
66 & $17.4 \pm 0.2$ & $-40 \pm 3$ & $-32 \pm 3$ & $-25 \pm 3$ & $0.52 \pm 0.00$ \\
\hline
\end{tabular}

$\Delta \mathrm{Cp}$ occurred during the isothermic crystallization of lactose in the powders (from $43 \%$ of HR).

In the last part of the sorption isotherm (above $43 \%$ of HR), these two powders behaved almost equally, the NCW being within the same range as the $\mathrm{CW}$ in terms of $T_{g}$, crystallization ratio and low value of $\Delta \mathrm{Cp}$.

The $\mathrm{T}_{\mathrm{g}}$ and $\Delta \mathrm{Cp}$ values obtained with skim milk (SM; Tab. IV) and their evolution among the sorption isotherms were comparable with those obtained with NCW. However, the extent of the modifications observed was limited compared with those of NCW, reflecting a smaller proportion of amorphous lactose in skim milk at the beginning of the isotherm $\left(a_{\mathrm{w}}=0.11\right)$. Indeed, the amorphous lactose content can be obtained from the total lactose content (Tab. I) and the crystallization ratios measured for each of these powders (Tabs. II and IV). At $0.11 \mathrm{a}_{\mathrm{w}}$, it was, respectively, equal to $54.6 \%$ and $69.3 \%$ for SM and NCW, leading to a lower $\Delta \mathrm{Cp}$ value for SM.

In the case of hydrolyzed skim milk (HSM; Tab. V), the values of free water content and $\mathrm{T}_{\mathrm{g}}$ were higher and lower, respectively than those of skim milk at the same water activity. In accordance with the literature [7, 18], these results are explained by the fact that hydrolysis of lactose in glucose and galactose leads to an increase in powder hygroscopicity and, in accordance to the $T_{g}$ values of these monosaccharides (Tab. VIII), to a reduction in the overall $\mathrm{T}_{\mathrm{g}}$ value of the powder. $\Delta \mathrm{Cp}$ was significantly 
Table VI. NPCS powder: free water content, glass transition temperature $\left(T_{g}\right)$ and change in heat capacity $(\Delta \mathrm{Cp})$ at various relative humidities.

\begin{tabular}{lccccc}
\hline $\begin{array}{l}\text { Relative } \\
\text { Humidity } \\
(\%)\end{array}$ & $\begin{array}{c}\text { Free water } \\
\text { content } \\
\left(\mathrm{g} \cdot 100 \mathrm{~g}^{-1} \mathrm{TS}\right)\end{array}$ & $\begin{array}{c}\text { Glass transition } \\
\text { temperature } \\
\left(\text { onset }-{ }^{\circ} \mathrm{C}\right)\end{array}$ & $\begin{array}{c}\text { Glass transition } \\
\text { temperature } \\
\left(\text { inflection }-{ }^{\circ} \mathrm{C}\right)\end{array}$ & $\begin{array}{c}\text { Glass transition } \\
\text { temperature } \\
\left(\mathrm{endset}-{ }^{\circ} \mathrm{C}\right)\end{array}$ & $\begin{array}{c}\text { Change in heat } \\
\text { capacity } \\
\left(\mathrm{J} \cdot \mathrm{g}^{-1} \cdot{ }^{\circ} \mathrm{C}^{-1}\right)\end{array}$ \\
\hline 11 & $8.0 \pm 0.1$ & $112 \pm 3$ & $122 \pm 0$ & $130 \pm 2$ & $0.34 \pm 0.03$ \\
22 & $9.9 \pm 0.1$ & $99 \pm 2$ & $103 \pm 0$ & $112 \pm 0$ & $0.37 \pm 0.05$ \\
33 & $11.2 \pm 0.2$ & $86 \pm 3$ & $99 \pm 2$ & $105 \pm 1$ & $0.48 \pm 0.04$ \\
39 & $11.6 \pm 0.1$ & $81 \pm 3$ & $90 \pm 2$ & $92 \pm 1$ & $0.53 \pm 0.04$ \\
\hline
\end{tabular}

Table VII. WPI powder: free water content, glass transition temperature (Tg) and change in heat capacity $(\Delta \mathrm{Cp})$ at various relative humidities.

\begin{tabular}{lccccc}
\hline $\begin{array}{l}\text { Relative } \\
\text { Humidity } \\
(\%)\end{array}$ & $\begin{array}{c}\text { Free water } \\
\text { content } \\
\left(\mathrm{g} \cdot 100 \mathrm{~g}^{-1} \mathrm{TS}\right)\end{array}$ & $\begin{array}{c}\text { Glass transition } \\
\text { temperature } \\
\left(\text { onset }-{ }^{\circ} \mathrm{C}\right)\end{array}$ & $\begin{array}{c}\text { Glass transition } \\
\text { temperature } \\
\left.\text { inflection }-{ }^{\circ} \mathrm{C}\right)\end{array}$ & $\begin{array}{c}\text { Glass transition } \\
\text { temperature } \\
\left(\text { endset }-{ }^{\circ} \mathrm{C}\right)\end{array}$ & $\begin{array}{c}\text { Change in heat } \\
\text { capacity } \\
\left(\mathrm{J} \cdot \mathrm{g}^{-1} \cdot{ }^{\circ} \mathrm{C}^{-1}\right)\end{array}$ \\
\hline 11 & $8.5 \pm 0.1$ & $102 \pm 1$ & $106 \pm 1$ & $112 \pm 3$ & $0.10 \pm 0.00$ \\
22 & $9.5 \pm 0.1$ & $90 \pm 3$ & $95 \pm 0$ & $106 \pm 1$ & $0.13 \pm 0.01$ \\
33 & $11.2 \pm 0.1$ & $77 \pm 3$ & $80 \pm 2$ & $85 \pm 3$ & $0.13 \pm 0.03$ \\
39 & $12.5 \pm 0.2$ & $49 \pm 3$ & $59 \pm 3$ & $66 \pm 2$ & $0.15 \pm 0.02$ \\
\hline
\end{tabular}

Table VIII. Calorimetric characteristics of various dairy ingredients.

\begin{tabular}{lccc}
\hline Dairy ingredients & $\begin{array}{c}\text { Dry glass transition temperature Change in heat capacity } \\
\left(\text { inflection }-{ }^{\circ} \mathrm{C}\right)\end{array}$ & References \\
\hline Water & -139 & 1.94 & {$[12]$} \\
Casein & 132 & 0.26 & Table VI; [12; 14; 15] \\
Whey proteins & 127 & 0.09 & Table VII; [14] \\
Lactose & 98 & 0.38 & {$[23]$} \\
Glucose & 31 & 0.24 & Table V; $[3,4,18]$ \\
Galactose & 30 & 0.24 & Table V; $[3,4,18]$ \\
\hline
\end{tabular}

higher for HSM than for SM, which could be due to the higher thermoplasticity of glucose and galactose as compared with lactose. This hypothesis needs, however, to be confirmed. For the whole sorption isotherm, the continuous evolution of $\Delta \mathrm{Cp}$ observed could have been due to the absence of crystallization of glucose and galactose (not measured).

The quasi-total elimination of lactose and minerals (WPI and NPCS powders) resulted in a significant increase in $\mathrm{T}_{\mathrm{g}}$ at a given $\mathrm{a}_{\mathrm{w}}$ (Tabs. VI and VII). Within the $\mathrm{a}_{\mathrm{w}}$ range investigated, and in agreement with the literature [12, 14, 15], whey proteins and caseins were more hygroscopic than the other powders, except for hydrolyzed skim milk. One interesting finding of this study relates to the values of $\Delta$ Cp obtained for caseins and whey proteins $\left(0.37\right.$ and $0.13 \mathrm{~J} \cdot \mathrm{g} \cdot{ }^{\circ} \mathrm{C}^{-1}$ at $0.22 \mathrm{a}_{\mathrm{w}}$, respectively). These differences can be explained both by their composition in amino acids and by their degree of organization [14].

Table VIII gives $\mathrm{T}_{\mathrm{g}}$ and $\Delta \mathrm{Cp}$ values for the different constituent types at $0.0 \mathrm{a}_{\mathrm{w}}$, given in the literature or linearly extrapolated from the results obtained in this study 


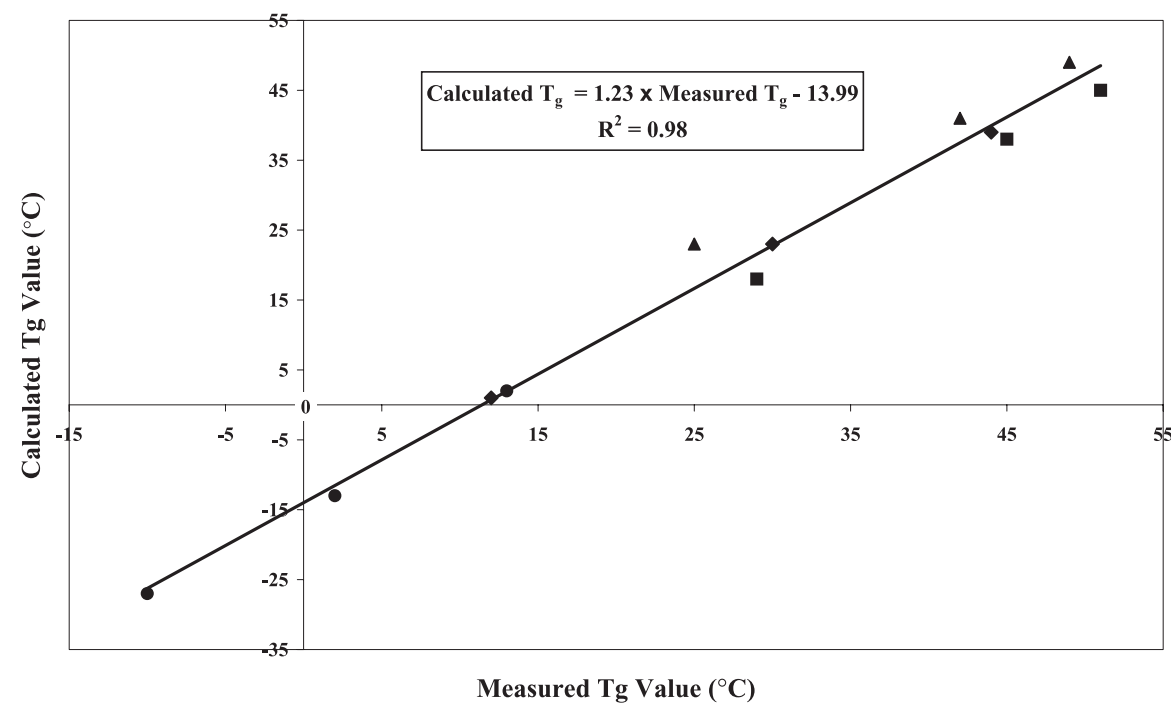

Figure 2. Calculated $\mathrm{T}_{\mathrm{g}}$ values as a function of measured $\mathrm{T}_{\mathrm{g}}$ inflection values for various dairy powders and $\mathrm{a}_{\mathrm{w}}$ in the range 0.11 to 0.33 . The different marker styles correspond to dairy powders. NCW; $\diamond$ : CW; $\Delta$ : SM; •: HSM.

at $\mathrm{a}_{\mathrm{w}}$ lower than 0.39 (included), i.e. before lactose crystallization (Tabs. II to VII). According to the data of Tables I and VIII, and using the Couchman-Karasz equation extended to more than three constituents (water, amorphous lactose, glucose and galactose, casein and whey proteins), it is possible to predict the $\mathrm{T}_{\mathrm{g}}$ value of each powder. Figure 2 represents the calculated (predicted) $\mathrm{T}_{\mathrm{g}}$ values as a function of measured $\mathrm{T}_{\mathrm{g}}$ inflection values for SM, HSM, $\mathrm{CW}$ and $\mathrm{NCW}, \mathrm{a}_{\mathrm{w}}$ being in the range 0.11 to 0.33 . The model obtained by linear regression is statistically significant at the $P<0.001$ level, with a $R^{2}$ coefficient of 0.98 . This shows that the extended Couchman-Karasz equation makes it possible to obtain a satisfying approximate inflection value of $\mathrm{T}_{\mathrm{g}}$, corresponding to the measured one $\pm 14{ }^{\circ} \mathrm{C}$ (intercept value of the model). Moreover, the higher the value of $\mathrm{T}_{\mathrm{g}}$, the better the estimation by the extended Couchman-Karasz equation, in accordance with the fact that the dry glass transition and $\Delta \mathrm{Cp}$ values used in this equation (Tab. VIII) were extrapolated from the results obtained at $\mathrm{a}_{\mathrm{w}}$ lower than 0.39 . The lack of fit and
Table IX. Calculation of stickiness and caking sensitivity index.

\begin{tabular}{ccc}
\hline $\begin{array}{c}\mathrm{T}-\mathrm{T}_{\mathrm{g}} \\
\left({ }^{\circ} \mathrm{C}\right)\end{array}$ & $\begin{array}{c}\Delta \mathrm{Cp} \\
\left(\mathrm{J} \cdot \mathrm{g}^{-1} \cdot{ }^{\circ} \mathrm{C}^{-1}\right)\end{array}$ & $\begin{array}{c}\text { Number of } \\
\text { points }\end{array}$ \\
\hline $\begin{array}{c}{\left[\mathrm{T}-\mathrm{T}_{\mathrm{g}}\right] \leq 5} \\
5<\left[\mathrm{T}-\mathrm{T}_{\mathrm{g}}\right] \leq 10\end{array}$ & $\begin{array}{c}\Delta \mathrm{Cp}<0.1 \\
0.1 \leq \Delta \mathrm{Cp}<0.2\end{array}$ & 0 \\
$10<\left[\mathrm{T}-\mathrm{T}_{\mathrm{g}}\right] \leq 15$ & $0.2 \leq \Delta \mathrm{Cp}<0.3$ & 2 \\
$15<\left[\mathrm{T}-\mathrm{T}_{\mathrm{g}}\right] \leq 20$ & $0.3 \leq \Delta \mathrm{Cp}<0.4$ & 3 \\
$20<\left[\mathrm{T}-\mathrm{T}_{\mathrm{g}}\right] \leq 30$ & $0.4 \leq \Delta \mathrm{Cp}<0.5$ & 4 \\
$30<\left[\mathrm{T}-\mathrm{T}_{\mathrm{g}}\right]$ & $0.5 \leq \Delta \mathrm{Cp}$ & 5 \\
\hline
\end{tabular}

underestimation of $\mathrm{T}_{\mathrm{g}}$ by the model can be explained both by the accuracy of measurement of $\mathrm{T}_{\mathrm{g}}$ and $\Delta \mathrm{Cp}$ and by not considering minerals and oligosaccharides (especially in the case of HSM) in calculation. However, this approach makes it easily possible to reach an approximate value for $\mathrm{T}_{\mathrm{g}}$ from the biochemical composition and the crystallization ratio of lactose. It is therefore a particularly interesting operational tool, already validated on an industrial scale. 
Table X. Powder behavior during drying and storage as a function of $\left[\mathrm{T}-\mathrm{T}_{\mathrm{g}}\right]$ and $\Delta \mathrm{Cp}$ values.

\begin{tabular}{|c|c|c|c|c|c|c|c|c|}
\hline Powder & $\begin{array}{c}\text { Free Moisture } \\
\text { content } \\
\left(\mathrm{g} \cdot \mathrm{kg}^{-1}\right)\end{array}$ & $\begin{array}{l}\text { Water } \\
\text { activity } \\
\left(25^{\circ} \mathrm{C}\right)\end{array}$ & $\begin{array}{c}\text { Calculated } \\
\mathrm{T}_{\mathrm{g}} \text { temperature } \\
\text { (inflection }-^{\circ} \mathrm{C} \text { ) }\end{array}$ & $\begin{array}{c}\text { Calculated } \\
\Delta \mathrm{Cp} \\
\left(\mathrm{J} \cdot \mathrm{g}^{-1} \cdot{ }^{\circ} \mathrm{C}^{-1}\right)\end{array}$ & $\begin{array}{l}\text { Powder tem- } \\
\text { perature T } \\
\left({ }^{\circ} \mathrm{C}\right)\end{array}$ & $\begin{array}{c}\mathrm{T}-\mathrm{T}_{\mathrm{g}} \\
\left({ }^{\circ} \mathrm{C}\right)\end{array}$ & SCSI & $\begin{array}{c}\text { Observed } \\
\text { effects on } \\
\text { powder }\end{array}$ \\
\hline \multicolumn{9}{|c|}{ STICKINESS PROPERTIES } \\
\hline \multirow{2}{*}{$\begin{array}{l}\text { Crystallized } \\
\text { sweet whey }\end{array}$} & $15.6 \pm 1$ & $0.13 \pm 0.01$ & 43 & 0.19 & $55 \pm 3$ & +12 & 3 & No [21] \\
\hline & $22.5 \pm 1$ & $0.22 \pm 0.02$ & 25 & 0.24 & $51 \pm 3$ & +26 & 6 & Yes [21] \\
\hline \multirow[t]{2}{*}{ Sodium caseinate } & $69.0 \pm 1$ & $0.24 \pm 0.02$ & 34 & 0.25 & $45 \pm 2$ & +11 & 4 & No \\
\hline & $83.0 \pm 2$ & $0.34 \pm 0.01$ & 22 & 0.48 & $40 \pm 3$ & +18 & 7 & Yes \\
\hline \multirow[t]{3}{*}{ Skim milk } & $40.7 \pm 2$ & $0.20 \pm 0.02$ & 53 & 0.26 & $60 \pm 2$ & +7 & 3 & No [21] \\
\hline & $60.0 \pm 1$ & $0.34 \pm 0.01$ & 35 & 0.31 & $42 \pm 3$ & +7 & 4 & No \\
\hline & $75.0 \pm 1$ & $0.41 \pm 0.02$ & 24 & 0.34 & $38 \pm 2$ & +12 & 5 & Yes \\
\hline \multicolumn{9}{|c|}{ CAKING PROPERTIES } \\
\hline \multirow[t]{2}{*}{ Skim milk } & 39.6 & $0.20 \pm 0.01$ & 55 & 0.26 & $20 \pm 2$ & -35 & 2 & No [21] \\
\hline & 45.2 & $0.26 \pm 0.01$ & 49 & 0.28 & $20 \pm 2$ & -29 & 2 & No [21] \\
\hline \multirow{2}{*}{$\begin{array}{l}\text { Non-crystallized } \\
\text { sweet whey }\end{array}$} & 23.9 & $0.10 \pm 0.02$ & 65 & 0.37 & $20 \pm 2$ & -4 & 3 & No \\
\hline & 81.6 & $0.39 \pm 0.01$ & 11 & 0.52 & $20 \pm 2$ & +9 & 6 & Yes \\
\hline
\end{tabular}

From these results, it is possible to consider the behavior of the different powders during drying (stickiness) and storage (caking) according to the range of variations in the parameters $\left[\mathrm{T}-\mathrm{T}_{\mathrm{g}}\right](\mathrm{T}$ corresponding to the temperature of the powder) and $\Delta \mathrm{Cp}$. An increase in $\left[\mathrm{T}-\mathrm{T}_{\mathrm{g}}\right]$ leads to an increase in the speed of physico-chemical changes (thermoplasticity, crystallization and Maillard reaction) in the product $[8,18]$. A stickiness and caking sensitivity index (SCSI, ranging between 0 and 10) can be determined for all powder, $\mathrm{a}_{\mathrm{w}}$ and temperature conditions. This index (Eq. (2)) simultaneously integrates the values of $\left[\mathrm{T}-\mathrm{T}_{\mathrm{g}}\right]$ (ranging between 0 and 5) and $\Delta \mathrm{Cp}$ (ranging between 0 and 5) (Tab. IX):

$$
\begin{aligned}
& \text { SCSI }= \text { Number of points } \\
& {\left[\mathrm{T}-\mathrm{T}_{\mathrm{g}}\right] } \\
&+ \text { Number of points } \\
& {\left[\Delta \mathrm{C}_{\mathrm{p}}\right] }
\end{aligned}
$$

Considering the SCSI value calculated from this equation makes it possible to anticipate powder behavior during drying and storage, from the most favorable case
(SCSI $\leq 4:$ no stickiness and/or no caking) to the most unfavorable (SCSI $\geq 6$ : high to very high stickiness or caking hazard). Table X gives examples of SCSI and the stickiness and caking tendency observed during drying and storage of skim milk, native phosphocaseinate suspension, non-crystallized whey and crystallized whey powders. The SCSI values are clearly in agreement with the observed effects on the powder.

\section{CONCLUSIONS}

In this study, the glass transition temperatures of various dairy powders were determined by differential scanning calorimetry, and were also calculated using the extended Couchman-Karasz equation, taking into account the values of $\mathrm{T}_{\mathrm{g}}, \Delta \mathrm{Cp}$ and the contents in each component category. In the case of lactose, it is necessary to consider the crystallization ratio, since the calculation of $\mathrm{T}_{\mathrm{g}}$ takes into account only the amorphous stăte of the components. The results obtained showed a good correspondence between measured and calculated $\mathrm{T}_{\mathrm{g}}$ inflection 
values, which provides easy access to this essential parameter for the control of drying and storage of dairy powders.

We particularly emphasize the importance of the $\Delta \mathrm{Cp}$ value in the understanding of the mechanisms and control of stickiness during drying and caking during storage. We propose the calculation of a stickiness and caking sensitivity index according to the values of $\left[\mathrm{T}-\mathrm{T}_{\mathrm{g}}\right.$ ] and $\Delta \mathrm{Cp}$, making it possible to anticipate the behavior of a powder under given temperature and $\mathrm{a}_{\mathrm{w}}$ conditions.

\section{REFERENCES}

[1] Aschaffenburg R., Drewry J., New procedure for the routine determination of the various non casein proteins of milk, in: Proceedings of the 15th Int. Dairy Congr., London, UK, vol. 3, 1959, pp. 1631-1637.

[2] Brennan J.G., Food dehydration: a dictionary and guide, Butterworth-Heinemann Ltd, Oxford, UK, 1994.

[3] Busin L., Mortazavi F., Bimbenet J.J., Étude expérimentale du séchage par atomisation de solutions sucrées, Ind. Alim. Agric. (1995) 485-489.

[4] Busin L., Buisson P., Bimbenet J.J., Notion de transition vitreuse appliquée au séchage par pulvérisation de solutions glucidiques, Sci. Aliments 16 (1996) 443-459.

[5] Couchman P.R., Karasz F.E., A classical thermodynamic discussion of the effect of composition on glass transition temperatures, Macromolecules 11 (1978) 117-119.

[6] Fauquant J., Maubois J.L., Pierre A., Microfiltration du lait sur membrane minérale, Tech. Lait. 1028 (1988) 21-23.

[7] Fernadez E., Schebor C., Chirife J., Glass transition temperature of regular and lactose hydrolyzed milk powders, Lebensm.-Wiss. Technol. 36 (2003) 547-551.

[8] Genin N., René F., Analyse du rôle de la transition vitreuse dans les procédés de conservation agro-alimentaires, J. Food Eng. 26 (1995) 391-408.

[9] Jouppila K., Roos Y.H., Water sorption and time-dependent phenomena of milk powders, J. Dairy Sci. 77 (1994) 1798-1808.

[10] Jouppila K., Roos Y.H., Glass transitions and crystallization in milk powders, J. Dairy Sci. 77 (1994) 2907-2915.
[11] Jouppila K., Kansikas J., Roos Y.H., Glass transition, water plastacization, and lactose crystallization in skim milk powder, J. Dairy Sci. 80 (1997) 3152-3160.

[12] Kalichevsky M.T., Blanshard J.M.V., Tokarczuk P.F., Effect of water content and sugars on the glass transition of casein and sodium caseinate, Int. J. Food Sci. Technol. 28 (1993) 139-151.

[13] Le Mestre M., Simatos D., La transition vitreuse : incidences en technologie alimentaire, Ind. Alim. Agric. (1990) 6-12.

[14] Matveev Y.I., Grinberg V.Y., Sochava I.V., Tolstoguzov V.B., Glass transition temperature of proteins. Calculation based on the additive contribution method and experimental data, Food Hydrocolloids 11 (1997) 125-133.

[15] Mauer L.J., Smith D.E., Labuza T.P., Effect of water content, temperature and storage on the glass transition, moisture sorption characteristics and stickiness of $\beta$-casein, Int. J. Food Prop. 3 (2000) 233-248.

[16] Pierre A., Fauquant J., Le Graët Y., Piot M., Maubois J.L., Préparation de phosphocaséinate natif par microfiltration sur membrane, Lait 72 (1992) 461-474.

[17] Roos Y.H., Water in milk products, in: Fox P.F. (Ed.), Advanced Dairy Chemistry, Vol. 3: Lactose, water, salts and vitamins, Chapman \& Hall, London, UK, 1997, pp. 303-346.

[18] Roos Y.H., Importance of glass transition and water activity to spray drying and stability of dairy powders, Lait 82 (2002) 478-484.

[19] Rowland S.J., The determination of nitrogen distribution in milk, J. Dairy Res. 9 (1938) 42-46.

[20] Schuck P., Dolivet A., Lactose crystallization: determination of $\alpha$-lactose monohydrate in spray dried dairy products, Lait 82 (2002) 413-421.

[21] Schuck P., Roignant M., Brulé G., Méjean S., Bimbenet J.J., Caractérisation énergétique d'une tour de séchage par atomisation multiple effet, Ind. Alim. Agric. 115 (1998) 9-14.

[22] Schuck P., Méjean S., Dolivet A., Jeantet R., Thermohygrometric sensor: A tool for optimizing the spray drying process, Innov. Food Sci. Emerg. Technol. 6 (2005) 45-50.

[23] Senoussi A., Dumoulin E.D., Berk Z., Retention of diacetyl in milk during spray-drying and storage, J. Food Sci. 60 (1995) 894-897, 905. 